\title{
都市のスカイラインのコント A STUDY ON CONTROL METHOD OF ロール手法に関する研究 URBAN SKYLINE IN JAPANESE CITIES
}

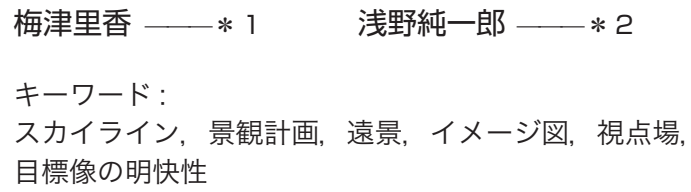

Keywords:

Skyline, Landscape plans, Far distant ciew, Image figures, Viewpoint, Clarity about skyline's goal

\section{1. 研究の背景と目的}

近年，高層建築物の増加を背景に，眺望景観に対する市民の関心 が高まっている。また，景観法施行以降，広域的な景観コントロー ルに取り組む自治体が見受けられるようになってきている。言うま でもなく, スカイラインは日々の建築活動の中で変化しうるもので あるが，視覚的に把握される都市の認識対象の一つであり，街並み を特徴づける要因の一つである。また，都市のシルエットであるス カイラインは, 広域的な眺望景観の中に位置づけられるため, その 都市の眺望景観のまとまりや特性を評価する一つの指標であるとい える。したがってスカイラインは，良好な眺望景観形成のために， 規制誘導す心゙き有力な対象であると考えられる。スカイラインの既 往研究には，その評価手法や認識手法に関するもの ${ }^{1)}$, 規制誘導方 法の研究 ${ }^{2)}$, 大規模開発によるスカイラインへの影響に関する研究 3)等が見られるが，スカイラインを多数同時に比較し，その規制誘 導等の一般的傾向を明らかにした研究はない。本研究では，景観法 に基づく景観計画を用いて，そこでのスカイラインを抽出し，国内 におけるスカイラインの捉えられ方とコントロール手法の傾向と特 色を明らかにすることを目的としている。

\section{2. 研究方法}

\section{1 スカイラインの定義}

Spiro Kostof によればスカイラインは，伝統的には「地面と空が 合わさる線」と意味付けられ ${ }^{4)}$, 摩天楼が建設され始めた 1890 年代 からは，「建築物が描く線」という概念が一般的になったとされてい る。しかし本研究では, スカイラインの意味が国内では多義的であ ると考えられるので, 景観計画に登場する “スカイライン”の語を そのまま集計し，その内容が何であるかを分類する手法をとる。

\section{2 研究の対象と方法}

本研究では, 比較的同時期（景観法施行から 5 年未満）かつ類似 した書式で，景観に関する計画や規制誘導方針，或はその方法を収 集できるという理由で, 景観法に基づく景観計画を調査対象とする。 景観計画は, 取組みの実効性が期待でき, 地域の景観特性等に応じ て自治体が独自に定める部分が非常に多く，規制誘導の特性を窅い
Rika UMETSU — $* 1$ Jun-ichiro ASANO - *2

This paper clarifies a control method of urban skyline by a research for 182 landscape plans. Urban skyline of all examples can be understood and classified by objects and regulatory methods. In Japan, there are a few cases of "Skyline making of Far Distant View" type, one of skyline's control methods, which mainly in Europe and the United States. The clearer skyline's image is, the easier we can discuss and guide because its basis is established in detail. Clarifying skyline's image and consensus formation with citizen are necessary for control method of urban skyline.

知れるという特徵がある。また, 都道府県や政令市といった，景観行 政団体となり景観計画策定が義務化されている公共団体を除けば, 法施行から早い時期の事例程, 法施行以前から景観行政に積極的で あった自治体の景観計画が多数含まれていることが考えられる。

まず, 2009 年 7 月 1 日時点の景観行政団体 406 団体中景観計画策 定団体 177 団体，全 182 景観計画を対象とし，景観計画の策定状況 を把握し, スカイラインの記述のある景観計画の数や地域的特性を 分析する (3.1，3.2)。次に, スカイライン記述のある 93 件を対象 に, 視対象と規制誘導方法の 2 つの尺度から分類・考察を行う (3.3)。 なお， 1 つの景観計画に複数の意味でスカイライン記述がある場合 は全て抽出・分類した。次に, 3.3 節で整理したスカイラインの対 象と規制誘導方法による分類毎にイメージ図のパターンと視点場・ 視対象の関係を抽出し, 景観計画におけるコントロール手法を考察 する (4 章)。また, 欧米におけるスカイラインの意味とその誘導方 法である「遠景形成型スカイライン」注1)を扱う景観計画策定団体 9 団体を対象にヒアリング調查を行い, 運用実態を把握すると共に, スカイラインの目標像の明快性によって分類する（5.1）。最後に, 各分類における具体的なスカイライン施策より，規制誘導の特性に ついて考察を行う（5.2）。以上より，本編をまとめて国内における スカイラインのコントロール手法の課題を述べる。

\section{3. 景観計画におけるスカイライン記述の現状}

\section{1 景観計画策定状況とスカイライン記述の推移}

2004 年の景観法制定以降, 2005 年 6 月施行から 2009 年 7 月まで の景観計画策定数とスカイライン記述数の推移を図 1 に示す。全体 的に右肩上がりに推移しており，ほぼ同じペースで増加している。 また，景観計画策定数におけるスカイライン記述数の割合はどの時 点でも $50 \%$ 前後となっている。2009 年 7 月 1 日時点でのスカイライ ン記述は, 景観計画 182 件中 93 件であり, その割合は $51 \%$ である。

\section{2 地域別景観計画件数とスカイライン記述の割合}

2009 年 7 月 1 日時点での地域別景観計画件数とスカイライン記述 の割合を図 2 に示す。景観計画件数では, 関東が最大の 43 件, 最小 は四国の 9 件である。スカイライン記述の割合を見ると，北海道の

\footnotetext{
戸田建設(侏) 修士 (工学)

2 豊橋技術科学大学建築・都市システム工学系 准教授・博士 (工学)

（干 441-8580＼cjkstart豊橋市天伯町字雲雀ケ丘 1-1）
}

\footnotetext{
TODA Corporation, M. Eng.

Assoc. Prof., Dept. of Architecture and Civil Engineering, Faculty of Technology, Toyohashi Univ. of Technology, Dr. Eng.
} 
64\%が最大となり, 次いで関東, 中部で ある。反対に小さい地域は, 東北, 近畿, 四国, 九州である。景観計画の件数とス カイライン記述の割合が共に大きい地域 は, 関東と中部であり, 景観やスカイラ インに対する関心の高さが窥える。

3.3 景観計画におけるスカイラインの

\section{対象と規制誘導方法}

表 1 では，全景観計画におけるスカイ ラインの対象と規制誘導手法を一覧して いる。対象は, 「山並み」, 「遠景」,「街並 み」,「ランドマーク」の 4 分類化が可能 であり注 2), 規制誘導では, 「保全」,「調和」, 「形成」の 3 分類化が可能である。分類の用 語の定義は表 1 に示寸。ここで「山並み」や 「ランドマーク」は目標とするスカイライン が既定物を対象とする為，固定的であるのに 対し，「遠景」や「街並み」は目標と寸るスカ イラインが変化しうるという点で性格が異な る。また,「調和」と「形成」の手法は各景観 計画中の記載に従って集計したものの区別が 判然としない部分があるが，「調和」は背景や 周辺に馴染ませる方法であり，「保全」と「形 成」の中間に位置する手法だと理解される。 表 1 より, 景観計画におけるスカイラインの 記述のされ方は「山並み保全」と「街並み調 和」が一般的であるということがわかる。一

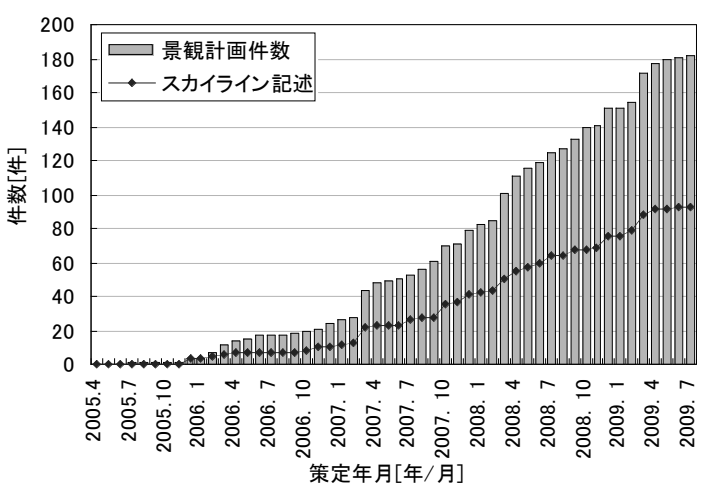

図 1 景観計画策定件数とスカイライン記述の推移

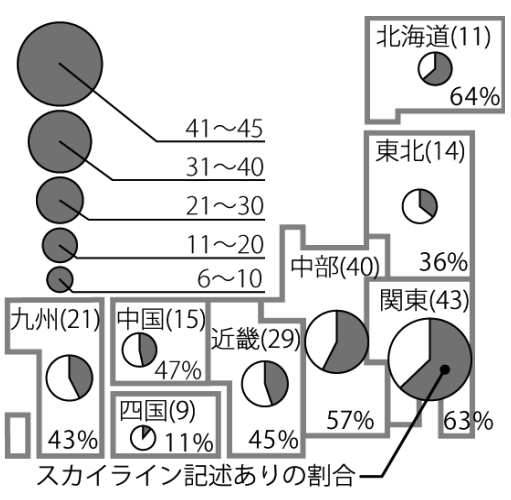

図 2 地域別景観計画策定件数と スカイライン記述の割合

表 1 景観計画におけるスカイラインの対象と規制誘導の方法

\begin{tabular}{|c|c|c|c|c|}
\hline & & 保 & 調 & 形 \\
\hline 対全 & & 輪郭線を乱す，遮ることを規制 & 背景·周辺に馴染ませるように誘導 & ある形状に形作ること \\
\hline $\begin{array}{l}\text { 山 } \\
\text { 並 }\end{array}$ & \begin{tabular}{|l} 
(山並み、棱線、樹木) \\
山の稜線等、山並みの輪郭 \\
線のみを対象とする
\end{tabular} & $\begin{array}{l}\text { 北海道, 清里町, 遠野市, 秩父市, } \\
\text { 世田谷区, 長野県, 松本市, 七尾 } \\
\text { 市, 可児市, 伊賀市, 宇治市, 倉吉 } \\
\text { 市, 岡山県, 瀬戸内市, 平戸市, 宮 } \\
\text { 崎市, 浦添市汭 } \\
\text {. - . 34 }\end{array}$ & $\begin{array}{l}\text { 長沼町, 仙台市, 伊勢崎市, 市原 } \\
\text { 市, 東京都, 世田谷区, 府中市, 江 } \\
\text { 東区, 柔ヶ崎市, 長野県, 飯田市, } \\
\text { 中津川市, 高島市, 大阪府, 萩市, } \\
\text { 内子町, 福岡県, 平戸市 } \\
\text {. . . 18 }\end{array}$ & 世田谷区 \\
\hline 景 & \begin{tabular}{|l|} 
(市街地の眺望、建築物群 \\
のシルエエ \\
市街地全体を対象とする
\end{tabular} & $\begin{array}{l}\text { 水戸市, 柏市, 鎌倉市, 長野県, 飯 } \\
\text { 田市, 京都市, 奈良県 }\end{array}$ & 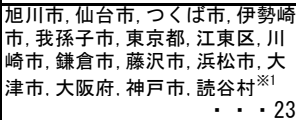 & $\begin{array}{l}\text { 仙台市, 水戸市, 東京都, 新宿区, } \\
\text { 江東区, 川崎市, 鎌倉市, 浜松市, } \\
\text { 京都府, 神戸市 }\end{array}$ \\
\hline 並 & $\begin{array}{l}\text { (市街地の街路、歴史的町 } \\
\text { 並み、家並み) } \\
\text { 街路景観や単体の建築物を } \\
\text { 対象とする }\end{array}$ & $\begin{array}{l}\text { 札幌市, 守谷市, 小山市, 長野県, } \\
\text { 飯田市, 新発田市, 京都市, 尾道 } \\
\text { 市, 福岡県, 宮崎市 }\end{array}$ & $\begin{array}{l}\text { 札幌市, 小樽市, 守谷市, 戸田市, } \\
\text { 東京都, 新宿区, 大磯町, 茅ヶ崎 } \\
\text { 市, 飯田市, 高岡市, 大垣市, 熱海 } \\
\text { 市, 守山市, 京都市, 松江市, 福岡 } \\
\text { 県, 熊本県, 鹿児島市※1 } \\
\text {. . . 48 }\end{array}$ & $\begin{array}{l}\text { 仙台市, 守谷市, 柏市, 江東区, 川 } \\
\text { 崎市, 横浜市, 小田原市, 秦野市, } \\
\text { 鎌倉市, 和市, 松本市, 静岡市, } \\
\text { 熱海市, 守山市, 京都市, 北九州 } \\
\text { 市, 宮崎市, 石垣市 }\end{array}$ \\
\hline 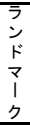 & 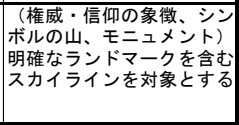 & $\begin{array}{r}\text { 盛岡市, 水戸市, 東京都, 世田谷 } \\
\text { 区, 長野県,松本市, 飯田市, 犬山 } \\
\text { 市, 伊賀市, 京都市, 鳥取市, 松江 } \\
\text { 市, 福岡県, 平戸市, 宮崎市 } \\
\cdot \cdot 15\end{array}$ & 東京都, 小田原市, 鳥取市 & 東京都 \\
\hline
\end{tabular}

※1山並み保全、遠景調和、街並み調和、街並み形成では、主要な景観行政団体を表記

表 2 景観計画におけるスカイラインの対象と規制誘導の方法

方，欧米でのスカイラインの意味とその誘導方法である「遠景形成」 は 10 件と少ない。また, 「遠景形成」には政令指定都市を含む大都 市が占めているという特色がある。

\section{4. 景観計画におけるイメージ図と視点場・視対象の記述}

\section{1 イメージ図表示と視点場・視対象の記述の有無}

景観計画において，イメージ図を用いることや明確な視点場を定 めることは, 景観形成基準をより詳細に示寸際に有効であると考え られる。表 2 には, スカイライン記述のある景観計画におけるイメ ージ図表示と視点場・視対象記述のある景観計画の件数を示す。

イメージ図表示のある景観計画数は一部を除き $80 \%$ 以上と多く, 景観計画においてスカイライン記述する際はイメージ図を用いる傾 向があるといえる。

対象が「街並み」の場合は, 視点場・視対象記述の割合が $35 \%$ 前 後と低い。一方, 対象が「ランドマーク」の場合と規制誘導の方法 が「保全」の場合には, 視点場の記述が $60 \%$ 以上であり, 「遠景形 成」の場合にはイメージ図表示, 視点場・視対象記述共に $80 \%$ 以上 と高い割合で記述されている。これらは, 視点場・視対象とイメー ジ図表示により，スカイライン計画が詳細に規定されている。

\section{2 スカイライン記述におけるイメージ図表示}

表 3 には，スカイライン記述時に用いられた全てのイメージ図を 抽出しており, 景観計画における規制誘導の表示のされ方のパター ンを整理し，それぞれに該当する件数を示している。

\begin{tabular}{|c|c|c|c|c|c|c|c|c|c|}
\hline \multirow{2}{*}{$\begin{array}{l}\text { 対 } \\
\text { 象 }\end{array}$} & \multirow{2}{*}{$\begin{array}{c}\text { 項 目 } \\
\text { (対象之规制誘導方法の各分類に二共通) }\end{array}$} & \multicolumn{2}{|c|}{ 保 全 } & \multicolumn{2}{|c|}{ 調 和 } & \multicolumn{2}{|c|}{ 形 成 } & \multicolumn{2}{|c|}{ 計 } \\
\hline & & $\begin{array}{l}\text { 件数 } \\
\text { (件) }\end{array}$ & $\begin{array}{l}\text { 割合 } \\
(\%)\end{array}$ & $\begin{array}{l}\text { 件数 } \\
\text { (件) }\end{array}$ & $\begin{array}{l}\text { 割合 } \\
(\%)\end{array}$ & $\begin{array}{l}\text { 件数 } \\
\text { (件) }\end{array}$ & $\begin{array}{l}\begin{array}{l}\text { 割合 } \\
(\%)\end{array} \\
\end{array}$ & $\begin{array}{l}\text { 件数 } \\
\text { (件) }\end{array}$ & $\begin{array}{l}\text { 割合 } \\
(\%) \\
\end{array}$ \\
\hline \multirow{4}{*}{$\begin{array}{l}\text { 山 } \\
\text { 並 }\end{array}$} & 視点場·視対象記述 ※1 & 13 & 61.9 & 4 & 50.0 & 0 & 0.0 & 17 & 56.7 \\
\hline & イメージ図表示※2 & 17 & 81.0 & 6 & 75.0 & 1 & 100.0 & 24 & 80.0 \\
\hline & $\begin{array}{l}\text { 視点場·視対象記述, } \\
\text { イメージ図表示のいずれか※3 }\end{array}$ & 21 & 61.8 & 8 & 44.4 & 1 & 100.0 & 30 & 56.6 \\
\hline & スカイライン記述件数 ※4 & 34 & - & 18 & - & 1 & - & 53 & - \\
\hline \multirow{4}{*}{ 遠 } & 視点場·視対象記述 & 2 & 66.7 & 4 & 33.3 & 5 & 83.3 & 11 & $\overline{52.4}$ \\
\hline & イメージ図表示 & 3 & 100.0 & 10 & 83.3 & 5 & 83.3 & 18 & 85.7 \\
\hline & $\begin{array}{l}\text { 視点場·視対象記述, } \\
\text { イメジ表示のいすれか }\end{array}$ & 3 & 50.0 & 12 & 52.2 & 6 & 60.0 & 21 & 53.8 \\
\hline & スカイライン記述件数 & 6 & - & 23 & - & 10 & - & 39 & - \\
\hline \multirow{4}{*}{$\begin{array}{l}\text { 街 } \\
\text { 並 } \\
\text { み }\end{array}$} & 視点場·視対象記述 & 1 & 33.3 & 6 & 33.3 & 3 & 50.0 & 10 & 37.0 \\
\hline & イメージ図表示 & 2 & 66.7 & 15 & 83.3 & 5 & 83.3 & 22 & 81.5 \\
\hline & \begin{tabular}{|l} 
視点場·視対象記述, \\
イメージ表表示のいずれか \\
\end{tabular} & 3 & 30.0 & 18 & 37.5 & 6 & 33.3 & 27 & 35.5 \\
\hline & スカイライン記述件数 & 10 & - & 48 & - & 18 & - & 76 & - \\
\hline \multirow{4}{*}{$\begin{array}{l}\bar{F} \\
\dot{1} \\
ト \\
\gamma \\
1 \\
\eta\end{array}$} & 視点場·視対象記述 & 8 & 61.5 & 2 & 66.7 & 1 & 100.0 & 11 & 64.7 \\
\hline & イメージ図表示 & 11 & 84.6 & 3 & 100.0 & 1 & 100.0 & 15 & 88.2 \\
\hline & \begin{tabular}{|l|} 
視点場·視対象記述, \\
イメージ表示のいずれか \\
\end{tabular} & 13 & 86.7 & 3 & 100.0 & 1 & 100.0 & 17 & 89.5 \\
\hline & スカイライン記述件数 & 15 & - & 3 & - & 1 & - & 19 & - \\
\hline \multirow{4}{*}{ 計 } & 視点場·視対象記述 & $\overline{24}$ & $\overline{60.0}$ & $\overline{16}$ & $\overline{39.0}$ & $\overline{99}$ & 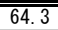 & $\overline{499}$ & $\overline{51.6}$ \\
\hline & イメージ図表示 & 33 & 82.5 & 34 & 82.9 & 12 & 85.7 & 79 & 83.2 \\
\hline & $\begin{array}{l}\text { 視点場·視対象記述, } \\
\text { イメジ図表示のいずれか }\end{array}$ & 40 & 61.5 & 41 & 44.6 & 14 & 46.7 & 95 & 50.8 \\
\hline & スカイライン記述件数 & 65 & - & 92 & - & 30 & - & 187 & - \\
\hline
\end{tabular}

※1 視点場・視対象記述: 視点場-視対象記述のある景観計画の件数と「視点場·視対象記 述, イメージ図表示のいずれか」の件数における割合

※2 イメージ図表示: イメージ図表示のある景観計画の件数と「視点場·視対象記述, イメー ジ図表示のいずれか」の件数における割合

※3 視点場・視対象記述，イメージ図表示のいずれか：視点場・視対象とイメージ図のいず れか, 又は両方の記述のある景観計画の件数と「スカイン 視点場・視対象とイメージ图のいす ※4 スカイライン記述件数 : スカイライン記述のある景観計画件数

表 3 より, スカイラインの対象と規制誘導の対象との位置関係に

は, 規制誘導の対象が「スカイライン前面の建築物」,「スカイライ ンを構成する建築物そのもの」,「スカイラインに対して背後の建築 物」の 3 種類が挙げられる。全体的に, スカイラインの対象別では, 
1A-(2)，2B-(1)，3B-(1)，4A-(1)等が多く，これらがそれぞれの対象の 主要な規制誘導方法であるといえる。よって, スカイラインの対象 が「山並み」や「ランドマーク」の場合, スカイラインの前面の建 築物がそのスカイラインを乱さないように規制誘導されており, 対 象が「遠景」と「街並み」の場合は, スカイラインを構成する建築 物に対して, 周辺との調和を図るよう規制誘導されているといえる。 また，対象が「遠景」の場合（2A-(2)，2B-(2)）に見られるように， 日本におけるスカイラインの捉えられ方は, 純粋な空と建築物との 境界線という意味だけでなく, 建築物群と背景の山並みとの境界線 の意味も含んでいることがいえる。

\section{3 スカイライン記述における視点場・視対象の関係}

スカイラインは, 見る位置によりその形状が変化するため, 視点 場の規定が重要であると考えられることから, 景観計画における視 点場と視対象の関係に注目寸る。表 4 には, 景観計画におけるスカ イライン記述の視点場・視対象の全体の関係を示す。視点場と視対 象の記述のある景観計画において, 視点場を 12 要素, 視対象を 4 要素に分類・整理した。また, 視点場の要素の a e を面的視点場, $\mathrm{f} \sim \mathrm{i}$ を線的視点場， j 1 を点的視点場とすることができる。

表 4 より, 視点場と視対象の関係は,「公園から建築物群」,「街路 沿道から山・森林」, 「街路沿道から建築物群」の組み合わせが $25 \%$
を超えており, 景観計画における視点場と視対象の関係性として主 要なものであるといえる。

次に, スカイラインの対象と規制誘導方法の分類別の視点場・視 対象の関係を表 5 に示す。

全体では,「山並み保全」における「河川沿岸から山・森林」と「街 路沿道から山・森林」,「街並み調和」における「街路沿道から建築 物群」が主要な視点場と視対象の関係であることがわかる。スカイ ラインの対象と規制誘導の方法別に見ると, 表 4 における視点場・ 視対象の全体の関係による傾向との相違が見られる。これは, 視対 象や規制誘導の方法によって視点場が変化することを示している。

スカイラインの対象が「山並み」と「遠景」の場合, 視点場の種 類が多く, その中でも「d. 公園」,「g. 河川沿岸」,「h. 街路沿道」, $\lceil j$. 橋」が, 分類毎の $60 \%$ 以上の関係に該当する視点場であり, 主要なものである。この場合, 面的視点場, 線的視点場, 点的視点 場の全てが含まれていることがわかる。一方で, スカイラインの対 象が「街並み」の場合は, 主要な視点場が線的視点場の「h. 街路沿 道」であり, 視対象は「1. 山・森林」, 「3. 建築物群」,「4. 建物単 体」と多様である。視点場・視対象共に種類が多い「ランドマーク 保全」の場合は, 全体の関係と共通寸る部分もあるが, 建築物群一 の見通しが少ないという相違点が読み取れる。

表 3 景観計画におけるスカイラインのイメージ図パターン

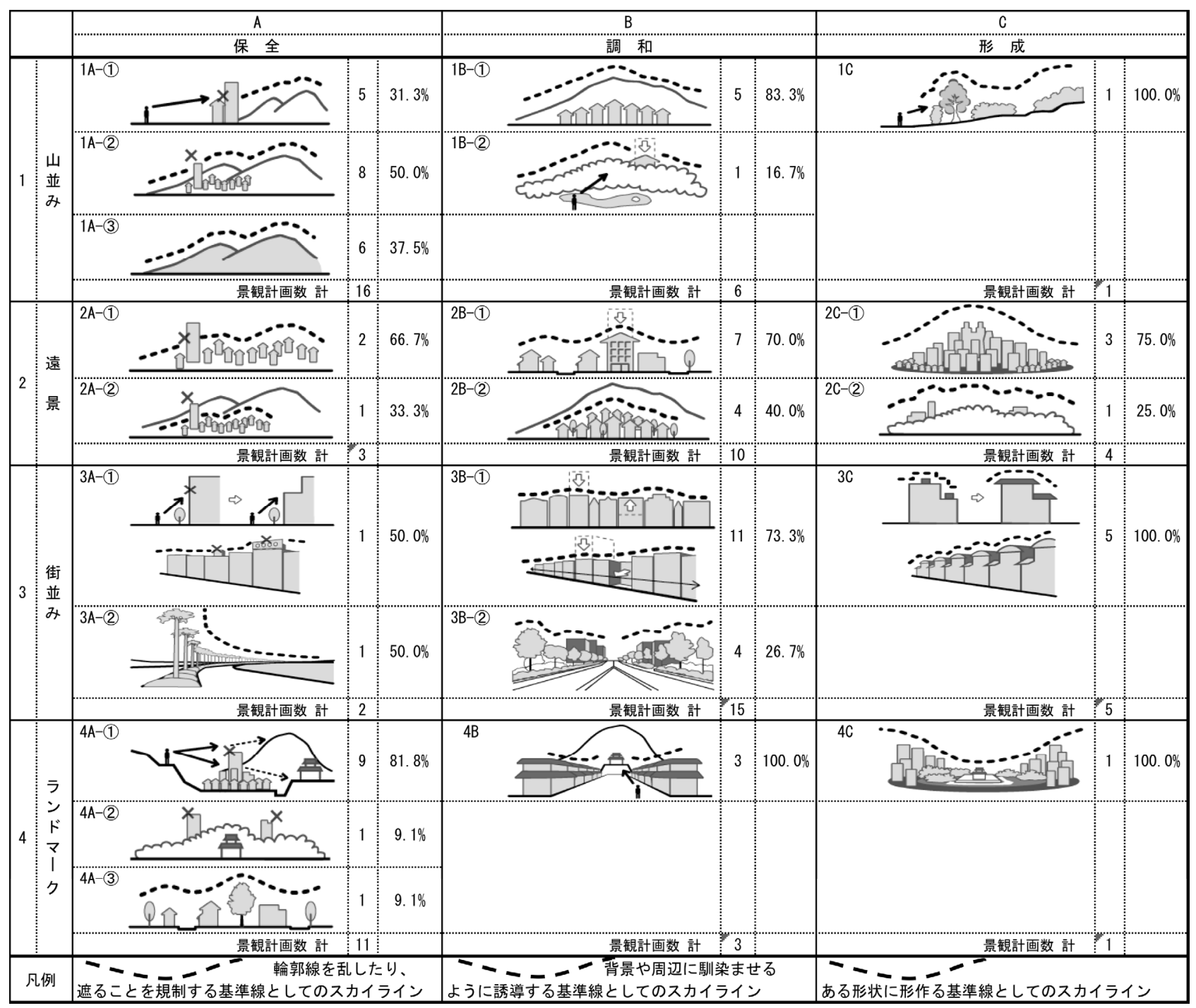


対象が「山並み」や「遠景」の場合, 視点場の要素が面的視点場, 点的視点場となり,「街並夕」の場合は線的視点場が主要となる。こ れより, 遠い景観を見るときは, 広いエリアの至る所, 或はある特 定の地点からの景観について規制誘導しており, 街並みといった中 近景に関しては街路からの景観に配慮し, 建物単体や屋根形状, 高 さの規制がなされていることがわかる。

\section{5. 遠景形成型スカイラインのコントロール手法}

\section{1 遠景形成型スカイライン計画の運用手法の分類}

前 2 章より, 景観計画におけるスカイライン記述のされ方は, ス カイラインの対象や視点場との位置関係により多様であるといえる。 しかし, 本来の意味での建築物群からなる遠景のスカイラインを対 象に, 形成を図る事例は少ない。したがって, 国内において, 建築 物群を対象として戦略的に規制誘導する手法の構築が不十分である と推測される。そこで, 遠景形成型スカイラインの施策を精査し, 国内におけるスカイラインの規制誘導手法の特性と課題を明らかに することが求められる。ここでは, 遠景形成型スカイラインを扱う 景観計画策定団体 10 都市のうち, 東京都を含む 9 都区市町村を調查 対象とした。市町村が策定する景観計画は, 都道府県が定める方針 等との整合性が求められ, さらに対象地域の特性を踏まえて詳細に 計画されている。また, 東京都においては, 都市化が顕著であり,
本来の意味での都市のスカイラインを扱う事例が多いと考えられる 為, 対象として適当だと考えられる。

表 6 には, 各景観計画策定団体におけるスカイライン計画の運用 実態を示す。ここでは, ヒアリング調査注 ${ }^{3)}$ により, 遠景のスカイ ラインの形成に係るとの回答があった運用手法を全て記載している。 景観法に基づく届出の対象は, 東京都と新宿区を除き, 高さが $15 \mathrm{~m}$ 〜20m, または延べ面積が $1000 \mathrm{~m}^{2}$ を超える建築行為とする規定が一 般的である。また, 川崎市と神戸市のように, 特定の景観形成地区 内における建築行為を対象とするものもある。規制誘導の方法を見 ると, 仙台市, 神戸市では地区別の高さ規定を設けており, 水戸市, 東京都，新宿区，江東区では眺望点からの見え方をシミュレーショ ンして検討するように指導している。川崎市, 浜松市, 神戸市では,

表 4 景観計画におけるスカイライン記述の視点場・視対象の関係

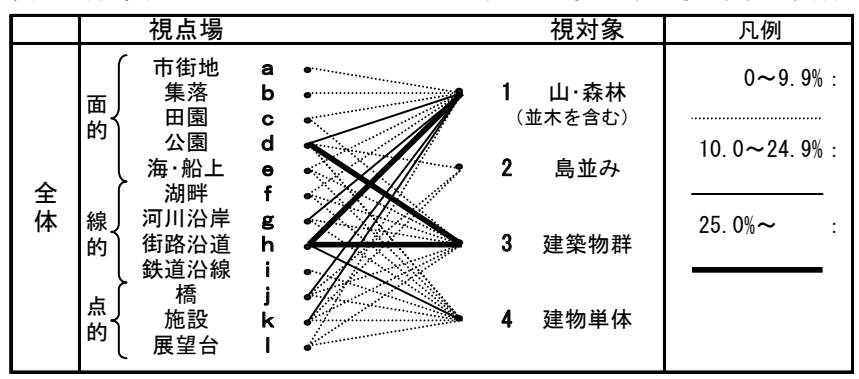

表 5 景観計画におけるスカイラインの対象と規制誘導方法の分類別視点場・視対象の関係

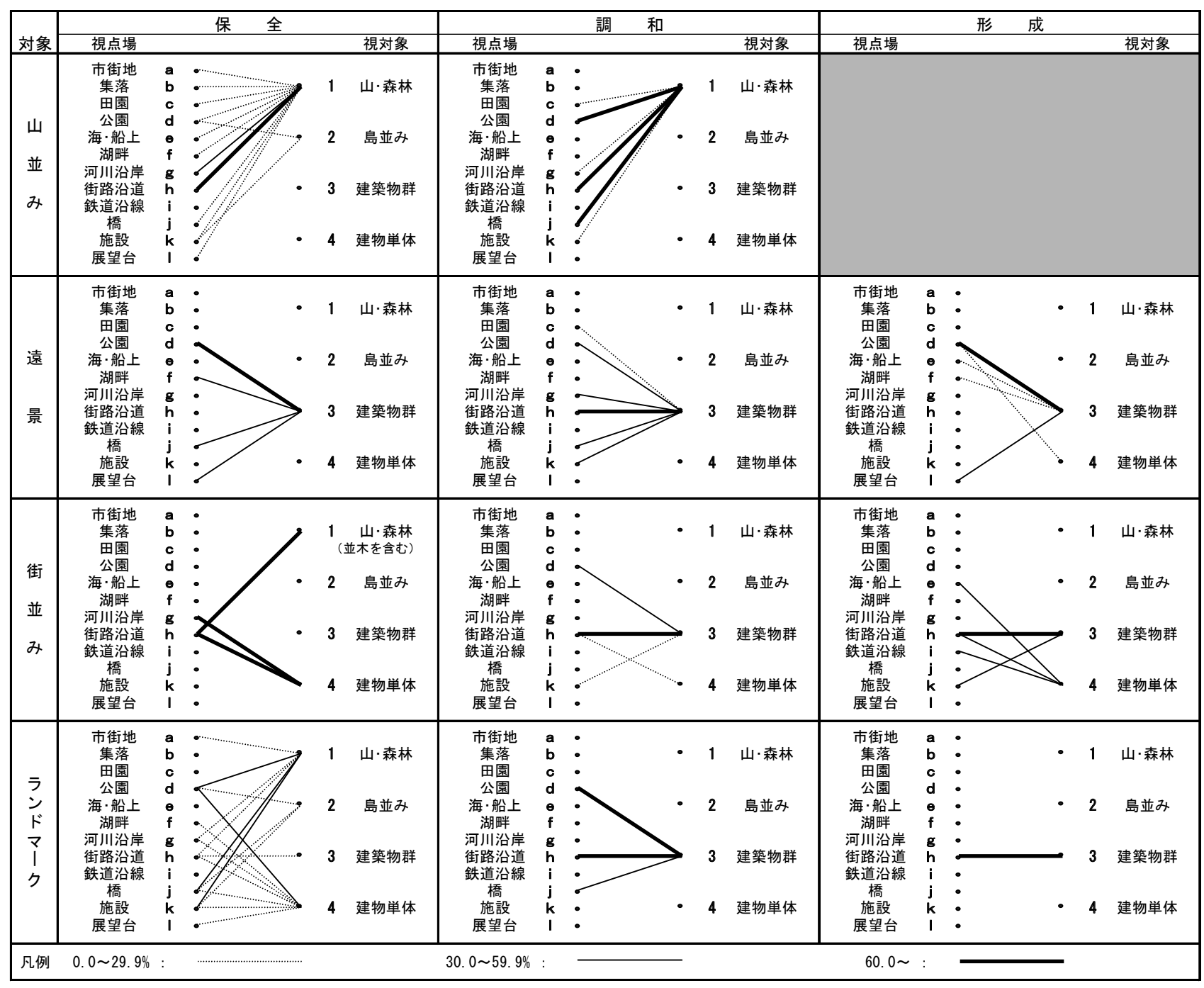


屋根の形状や建物の形態意匠について, 届出空口で指導している。

景観法以外の法・条例等によりスカイライン計画を担保している 景観計画策定団体は, 水戸市, 東京都, 新宿区, 鎌倉市である。水 戸市と鎌倉市では，都市計画法に基づく景観地区や高度地区指定を して高さ規制を図っている。東京都と新宿区の絵画館・新宿御苑周 辺地域では, 自主条例による大規模建築物等事前協議制度にて, 一 定規模以上の建築等行為に対して景観形成基準と協議の機会を設け ている。新宿区の都庁周辺地域では, 各エリア内の行為, または超 高層ビルを対象にした景観形成ガイドラインを設けている。

遠景形成型スカイラインを扱う各景観計画策定団体は，スカイラ インの目標像の明快性により, 3 分類化が可能である (表 7)。すでにその都市のスカイラインが形成されている場 合は目標像が明快であり, 形成途上である場合は目標像 が見えにくいため不明快である。また，現在のスカイラ インが形成途上であるが，行政の施策により自ずと都市 のスカイラインが形成されると予想される場合は, 目標 像が半明快であると定義する。

目標像が明快な場合は, 明確な視点場やランドマーク がある傾向にある。この場合, 現在の都市の形と目標像 が一致しているため, 保全する方向で規制誘導している。 目標像が不明快な場合は, 視点場やランドマークが特定 されておらず，スカイライン記述の対象地域が中心市街 地であり, 今後都市の形が変容することが見込まれる都 市が多い。また，具体的な目標像が無いため, 周辺との 調和を図るように規制誘導している。目標像が半明快の
場合では, 対象地域が中心市街地であり, 明確な視点場が定められ ている。ここでは, 景観法や都市計画法に基づく高さ制限により, その都市の目標像となるスカイラインが示されている。

5.2 具体的施策にみるスカイラインコントロールの特性

（1）明快：東京都・皇居周辺地域

東京都景観計画における景観形成方針には, 「皇居周辺地域に建つ 建築物群においては, 皇居等を中心に緩やかなすり鉢状のスカイラ インを描く」と記述されており, 一般的にも首都東京の象徵的な景 観であると共通に認識されている（図 3)。皇居周辺地域では, 特に 周辺景観に影響を及ぼす大規模建築物等については, 東京都景観計

表 7 各景観計画策定団体におけるスカイラインの目標像の明快性

\begin{tabular}{|c|c|c|c|c|c|c|c|}
\hline \multirow{2}{*}{$\begin{array}{l}\text { 景観計画 } \\
\text { 定団体 }\end{array}$} & \multirow[b]{2}{*}{ 対象地域 } & \multicolumn{6}{|c|}{ スカイライン(以下SL)の目標像の明快性 } \\
\hline & & SLの目標像 & 視点場 & ランドマーク & $\begin{array}{l}\text { SLの形 } \\
\text { 成度棌 }\end{array}$ & $\begin{array}{l}\text { 目標像 } \\
\text { の有無 }\end{array}$ & 明快性 \\
\hline 東京都 & 皇居周辺地域 & \begin{tabular}{|l|} 
皇居等を中心に緩やか \\
なすり鉢状のSL
\end{tabular} & $\begin{array}{l}\text { 皇居周辺の } \\
\text { 各眺望点 }\end{array}$ & 皇居 & 高 & 有 & \multirow{5}{*}{ 明快 } \\
\hline \multirow[t]{2}{*}{ 新宿区 } & \multirow{2}{*}{$\begin{array}{l}\text { 明治神宮聖德記念 } \\
\text { 絵画館周辺区域 } \\
\text { 新宿御苑周辺区域 }\end{array}$} & \multirow{2}{*}{ 袁辺の建築物群と統一 } & $\begin{array}{l}\text { 絵画館の } \\
\text { 眺望点 }\end{array}$ & 絵画館 & \multirow[t]{2}{*}{ 高 } & \multirow[t]{2}{*}{ 有 } & \\
\hline & & & 新宿御苑 & - & & & \\
\hline 江東区 & 清澄庭園周辺地区 & $\begin{array}{l}\text { 周辺の建築物群と統一 } \\
\text { 感のSL }\end{array}$ & 清澄庭園 & - & 高 & 有 & \\
\hline 鎌倉市 & 鎌倉市都市景域 & 水平に伸びるSL & - & 山並み & 高 & 有 & \\
\hline 仙台市 & 仙台市中心市街地 & 立体感のあるSL & 仙台城 & - & 低 & 有 & \multirow{2}{*}{ 半明快 } \\
\hline 水戸市 & 水戸市中心市街地 & $\begin{array}{l}\text { 水戸芸術館を中心とし } \\
\text { た=SL }\end{array}$ & 千波湖畔 & $\begin{array}{c}\text { 水戸芸術館 } \\
\text { タワー }\end{array}$ & 低 & 有 & \\
\hline 東京都 & 副都心 & まとまりのあるSL & - & - & 低 & 無 & \multirow{5}{*}{ 不明快 } \\
\hline 新宿区 & 都庁周辺地域 & 都庁を中心としたSL & - & 都庁 & 低 & 無 & \\
\hline 川崎市 & 川崎市中心市街地 & $\begin{array}{l}\text { SLに配虜した質の高い } \\
\text { 形態·意匠 }\end{array}$ & - & - & 低 & 無 & \\
\hline 浜松市 & 浜松市中心市街地 & $\begin{array}{l}\text { 広域交流圏の拠点にふ } \\
\text { さわしい }\end{array}$ & - & - & 低 & 無 & \\
\hline 神戸市 & 須磨·舞子地域 & 屋根の形態は軽快なSL & - & - & 低 & 無 & \\
\hline
\end{tabular}

※1「目標像の有無」: 景観計画等での SL 記述の具体性や視点場·ランドマーク設定の有無より判断。ス カイラインの形成度: 既にスカイラインを形成している場合高、形成途上の場合二低と表記。目標像がある 場合は、目標像に対する充足性により判断。目標像が無い場合は、過去の実績からみて高層建築の立

表 6 各景観計画策定団体におけるスカイライン計画の運用実態

\begin{tabular}{|c|c|c|c|c|c|c|}
\hline \multirow{2}{*}{$\begin{array}{l}\text { 景観計画 } \\
\text { 策定団体 }\end{array}$} & \multirow{2}{*}{ 対象地域 } & \multicolumn{2}{|l|}{ 景観法に基づく届出 } & \multicolumn{3}{|c|}{ 景観法以外の法・条例・計画における規制誘導 } \\
\hline & & $\begin{array}{c}\text { 届出対象行為 } \\
\end{array}$ & 規制誘導方法 & 根拠 & 対象行為 & 運用手法 \\
\hline 仙台市 & 仙台市中心市街地 & 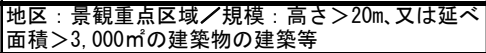 & 地区別高さ制限 & - & - & - \\
\hline 水戸市 & 水戸市中心市街地 & $\begin{array}{l}\text { (通常) 規模 : 高さ }>15 \mathrm{~m} 、 \text { 又は建築面積 }>1,000 \mathrm{~m}^{2} \\
\text { 建築物の建築 } \\
\text { 等 } \\
\text { (特定)規模 : 高さ }>45 \mathrm{~m} 、 \text { 又は延べ面積 }>10,000 \mathrm{~m}^{2} \\
\text { の建築物等の建築等 }\end{array}$ & $\begin{array}{l}\text { 主要な視点場からの高さの } \\
\text { シミュレーション } \\
\text { 水戸市都市景観専門委員に } \\
\text { よる事前協議 }\end{array}$ & (都市計画法) 高度地区 & 地区内での行為 & \\
\hline \multirow[t]{3}{*}{ 東京都 } & 皇居周辺地域 & $\begin{array}{l}\text { 地区: 一般地域/規模 : 高さミ60m、又は延べ面積 } \\
\geqq 30,000 \mathrm{~m}^{2} \text { の建築物の建築等 } * 1\end{array}$ & $\begin{array}{l}\text { 主要な眺望点からの見え方 } \\
\text { を検討 }\end{array}$ & $\begin{array}{l}\text { (東京都景観条例) 大規模建築物等 } \\
\text { の建築等にに係る事前協議制度 } \\
\text { 建築物のデザイン評価指針 }\end{array}$ & \begin{tabular}{|l} 
都市開発諸制度 年適 $^{-1}$ \\
用する建築物の建築等
\end{tabular} & 事前協議 \\
\hline & & & & $\begin{array}{l}\text { 大手町·丸の内·有楽町地区まちづ } \\
\text { くりガイドライン }\end{array}$ & \begin{tabular}{|l} 
大手町·丸の内·有楽町 \\
地区での大規模建築等
\end{tabular} & \\
\hline & 副都心 & $\begin{array}{l}\text { 地区：一般地域/規模 : 高さ } \geqq 60 \mathrm{~m} \text { 、又は延べ面積 } \\
\geqq 30,000 \mathrm{~m}^{2} \text { 建築物の建等 }\end{array}$ & $\begin{array}{l}\text { 主要な眺望点からの見え方 } \\
\text { を検討 }\end{array}$ & $\begin{array}{l}\text { (東京都景観条例)大規模建築物等 } \\
\text { の建築等に係る事前協猙制度 }\end{array}$ & \begin{tabular}{|l} 
都市開発諸制度を適用 \\
する建築物の建築等
\end{tabular} & 事前協議 \\
\hline \multirow[t]{7}{*}{ 新宿区 } & $\begin{array}{l}\text { 明治神宮聖德記念 } \\
\text { 絵画館周辺区域 }\end{array}$ & $\begin{array}{l}\text { 地区: 一般地域/規模: 高さ }>60 \mathrm{~m} \text { 、又は延べ面積 } \\
>30,000 \mathrm{~m}^{2} \text { の建築物の建築等 }\end{array}$ & $\begin{array}{l}\text { 主要な眺望点からの見え方 } \\
\text { を検討 }\end{array}$ & $\begin{array}{l}\text { 新宿区が許可する総合設計の建築 } \\
\text { 物等に係る景観形成ガイドライン } \\
\text { エリア別景観形成ガイドライン }\end{array}$ & \begin{tabular}{|l|} 
延べ面積 $10,000 \mathrm{~m}^{2}$ 未満 \\
の総合設計※3 \\
エリア内での行為
\end{tabular} & 事前協議 \\
\hline & 新宿御苑周辺区域 & $\begin{array}{l}\text { 地区: 新宿御苑みどりと眺望保全地区/規模: 高 } \\
\text { さ＞20m、筑物の建築 }\end{array}$ & $\begin{array}{l}\text { 新宿御苑内の主要な眺望点 } \\
\text { からの覞えの方のシシ }\end{array}$ & $\begin{array}{l}\text { 新宿区が許可する総合設計の建築 } \\
\text { 物等に係る景観形成ガイドライン }\end{array}$ & $\begin{array}{l}\text { 延べ面積 } 10,000 \mathrm{~m}^{2} \text { 末満 } \\
\text { の総合設計 }\end{array}$ & 事前協議 \\
\hline & & 等 & ション & エリア別景観形成ガイドライン & エリア内での行為 & \\
\hline & 都庁周辺地域 & 地区：一般地域／規模：高さ >60m、又は延べ面 & 主要な眺望点からの見え方 & (都市計画法)都市計画審議会 & 地区計画決定案件 & \\
\hline & & |積＞30,000m²の建築物の建築等 & 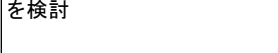 & $\begin{array}{l}\text { 新宿区が許可する総合設計の建築 } \\
\text { 物に係る景観形成ガイドライン }\end{array}$ & $\begin{array}{l}\text { 延ベ面積 } 10,000 \mathrm{~m}^{2} \text { 未満 } \\
\text { の総合設計 }\end{array}$ & 事前協議 \\
\hline & & & & エリア別景観形成ガイドライン & エリア内での行為 & \\
\hline & & & & 広域的な景観形成ガイドライン & 高さ $>60 \mathrm{~m}$ 建築物 & \\
\hline 江東区 & 清澄庭園周辺地区 & 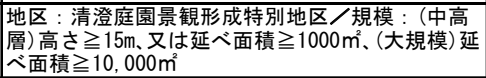 & $\begin{array}{l}\text { 庭園内部の主要な眺望点か } \\
\text { らの見えの方のシミュレー } \\
\text { ション }\end{array}$ & - & - & - \\
\hline 川崎市 & 川崎市中心市街地 & 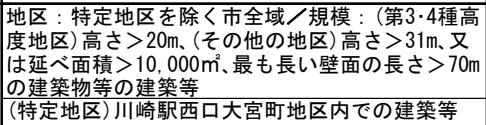 & $\begin{array}{l}\text { 景観作法、市域の骨格をつく } \\
\text { る景観形成方針、建築物等の } \\
\text { 用途別の景観形成方針との } \\
\text { 整合についての指導 } \\
\text { 形態意匠に係る行為の制限 }\end{array}$ & - & - & - \\
\hline 鎌倉市 & 鎌倉市都市景域 & 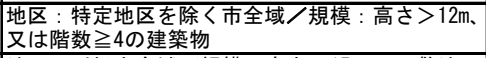 & $\begin{array}{l}\text { 眺望点からの見え方と高さ } \\
\text { の指導 }\end{array}$ & (都市計画法)景観地区, 高度地区 & 地区内での行為 & \\
\hline 浜松市 & 浜松市中心市街地 & $\begin{array}{l}\text { 地区: 浜松市全域/規模: 高さ }>15 \mathrm{~m} \text { 、同一敷地に } \\
\text { おけるる建築物の建築面積の合計 }>1,000 \mathrm{~m}^{2} \text { 建築 } \\
\text { 物の建築等 }\end{array}$ & $\begin{array}{l}\text { 大規模建築物等の行為の届 } \\
\text { 出に係る景観形成基に基 } \\
\text { づく事前協議 }\end{array}$ & - & - & - \\
\hline \multirow[b]{2}{*}{$\begin{array}{l}\text { 神尸市 } \\
※ 1 \\
※ 2\end{array}$} & 須磨·舞子地域 & 須磨・舞子海岸都市景観形成地域内での建築等 & 高さ制限、屋根形状の指導 & - & - & - \\
\hline & 官 & 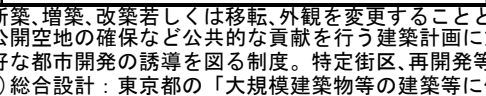 & & E & & \\
\hline
\end{tabular}


画に基づく「建築物のデザイン評価指針」による協議（以下，デザ イン協議) が設けられている。これまでの 3 件のデザイン協議では, 建物の意匠や素材, 色彩等の意見が，東京都景観審議会より出され ている。明確なスカイラインの目標像があるため, 複数の視点場や 眺望計画が設定される等，建築物の高さやボリュームの遵守は基礎 的事項と考えられており，より細部の計画に関する協議までを射程 に収めているとみられる。したがって，皇居周辺地域は，極めて先 進的なスカイラインの運用の仕方をしているといえる。

（2）不明快：川崎市

川崎市は市街地の開発によりスカイラインが形成途上であるため, 明快な目標像がない事例であると判断される。川崎市は, 景観法に 基づく届出のみで運用しているのだが，景観計画届出マニュアルに は，他都市を例に挙げて建築物群としてのスカイラインの考え方を 述べている（図 4)。川崎市では, 個々の建築物に配慮した結果, 形 成されるものがスカイラインであるという考えから，個々の建築物 を対象に形態意匠や規模等の誘導を図っている。目標像が明快でな いため，保全的な規制を行うのではなく，個別に行政と事業者の間 で景観の協議を重ね，適切なスカイラインの形成を目指している。

( 3 ）半明快 : 水戸市

水戸市では, 2010 年 12 月 1 日に高度地区を指定したばかりであ り，明確な視点場やランドマークはあるものの，現在のスカイライ ンは形成途上であるといえる。高さ規制值の考え方には,「水戸芸術 館タワーを中心に周辺に下がっていくスカイライン」が示されてい る（図 5)。また，高さ制限だけでは，形態意匠等の誘導が不十分で あると考えられるため，水戸市では，数值的に高さの規制をし，景 観計画による景観形成基準によって形態意匠や見え方等の定性的基 準の誘導を図るといった手法により運用している。また，この手法 は，目標像が明快である鎌倉市と同様の運用手法である。

\section{6. まとめ}

本研究では，景観計画の中に登場するスカイラインを対象に，国 内におけるスカイラインの捉えられ方を明らかにした。

(1)景観計画においてスカイライン記述は，その対象を「山並み」，「遠 景」,「街並文」,「ランドマーク」, 規制誘導の方法を「保全」,「調和」, 「形成」と 12 分類が可能である。また，規制誘導方法の 3 者で明確 な区別が難しい場合もあるが，「保全」と「形成」の中間的手法が「調 和」である。

(2)国内においてスカイラインは，眺望景観における背景を指寸場合 と，前景の建築物群からなる連なりを指す場合がある。

(3)欧米でのスカイラインの対象と規制誘導方法である「遠景形成型 スカイライン」を扱う事例は少数だが，大都市が占めている。

(4)ランドマークがある場合や眺望保全を図ろうとする場合は, 明確 な視点場を設定し，より詳細な基準を示寸傾向にある。

次に，遠景形成型スカイラインについて，目標像の明快性による コントロール手法を分類し，規制誘導の特性と課題を整理する。目 標像の明快性と運用手法からみた対象都市の分布図を図 6 に示寸。 (5)目標像が明快な場合は，目標像が明快であるが故に，より詳細な 規制誘導が可能である。現状では，大規模建築物等事前協議と景観 地区等を使った，かなり詳細で先進的運用がされている。

(6)目標像が不明快な場合は, 景観法に基づく届出のみの運用が多い。

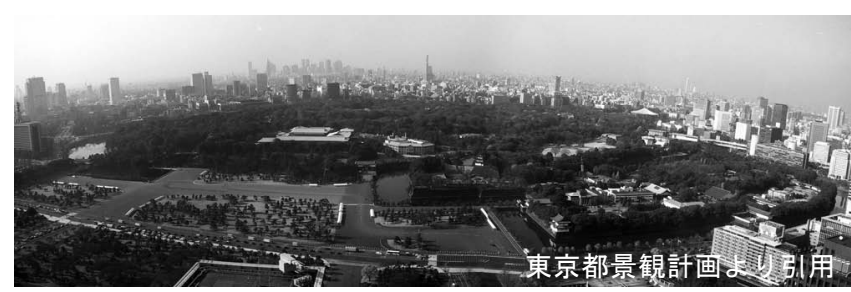

図 3 皇居周辺のスカイラインのイメージ写真

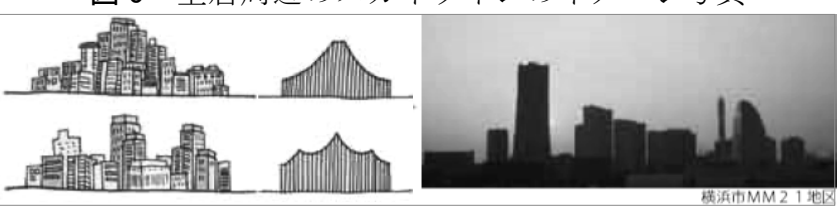

川崎市景観計画届出マニュアルより引用

図 4 景観計画届出マニュアルにおけるスカイラインイメージ

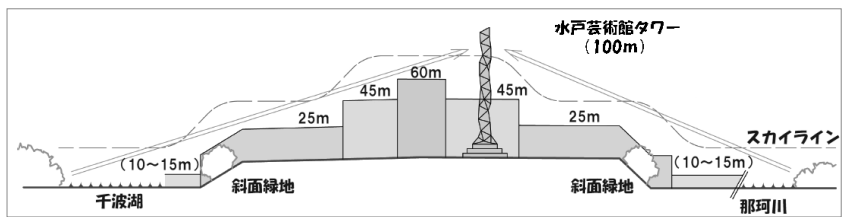

図 5 水戸市の高度地区における規制值の考え方

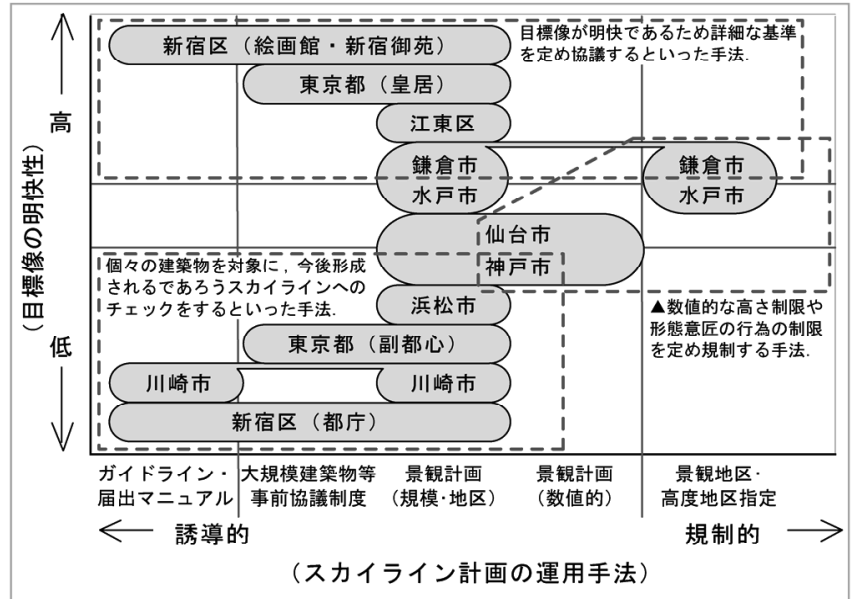

図 6 スカイライン目標像の明快性における運用手法 スカイラインが形成途上であるため目標像が見えにくく，議論が尽 くせないという現状がある。

(7)目標像が半明快な場合は，景観法や都市計画法に基づく高さ規定 を設けている。高さの数值的基準は，適合の評価がし易いが，スカ イラインに係る高さ以外の項目の誘導が不十分である。

以上より，将来像となるスカイラインのイメージを明快に示すほ ど，詳細な規制誘導を図ることができる。しかし，形成途上である 都市の方が多いため, そこに遠景形成型スカイラインコントロール の難しさがあるといえる。

脚注

注 1)欧米のスカイラインの事例として，例えばサンフランシスコにおけるス カイラインコントロールが有名である (参考文献 5)) 注 2) 対象の分類の内, 「遠景」は街並みの遠景であり,「街並み」は近景や 中景の街並みとして考えることができる。

注 3) ヒアリング調査は, 仙台市, 水户市, 東京都, 新宿区, 江東区, 川崎市, 鎌倉市, 浜松市, 神戸市の各景観計画担当課に対して行った。

\section{参考文献}

1）亀井栄治，月尾嘉男：スカイラインのゆらぎとその快適感に関する研究， 日本建築学会計画系論文報告集 第 432 号, pp. 105-111, 1992

2) 張松, 西村幸夫: 上海外灘歴史地区の景観保全計画に関寸る研究, 日本建

築学会計画系論文集第 496 号, pp. 125-130, 1997 構成されるスカイライン, 日本建築学会大会学術講演梗概集, pp. $721-722,2007$

4) Spiro Kostof, The City Shaped, Bulfinch Pr, 1993.5

5) Wayne Attoe, Skylines, Willy, 1981

[2011 年 6 月 2 日原稿受理 2011 年 8 月 17 日採用決定］ 